\title{
THE ONCOLOGIC RADIOTHERAPY EXPERIENCE FOR PATIENTS: A POISON-DRUG ${ }^{1}$
}

\author{
Rosani Manfrin Muniz ${ }^{2}$ \\ Marcia Maria Fontão Zago ${ }^{3}$
}

Muniz RM, Zago MMF. The oncologic radiotherapy experience for patients: a poison-drug. Rev Latino-am Enfermagem 2008 novembro-dezembro; 16(6):998-1004.

The study aimed at understanding the patients' experience with oncologic radiotherapy. The anthropological interpretative approach and the ethnographic method guided the investigation. Ten patients took part in the study. They were of both genders, within the age range from 34 to 80 years old and monitored during radiotherapy treatment. Data were collected through semi-structured interviews, participative observation and medical records. The analysis of the respondents' statements allowed for the identification of the units of meaning: The encounter with radiotherapy, the body as a vehicle for radiotherapy action and alternative healthcare practices that relieved the effects of the treatment. We understand that the oncologic radiotherapy experience meant the need to submit to a therapy with a characteristic of a poison-drug, which causes fear, but was necessary, whether the goal was cure or even cancer survival.

DESCRIPTORS: neoplasms; radiotherapy; anthropology, cultural; culture; nursing

\section{LA EXPERIENCIA DE LOS PACIENTES SOMETIDOS A RADIOTERAPIA ONCOLÓGICA: UNA MEDICINA-VENENO}

El estudio tuvo como objetivo comprender la experiencia de los pacientes sometidos a radioterapia oncológica. El abordaje de la antropología interpretativa y el método etnográfico orientaron la investigación. Los participantes del estudio fueron diez pacientes de ambos sexos, en el intervalo de edad de 34 a 80 años, acompañados durante el tratamiento radioterápico. Los datos fueron recolectados por entrevistas semi-estructuradas, observación de participante y levantamiento en registros. El análisis de los discursos de los informantes posibilitó identificar las unidades de significado: el encuentro con la radioterapia, el cuerpo como vehículo de acción de la radioterapia y las prácticas alternativas de cuidado para aliviar los efectos del tratamiento. Comprendemos que la experiencia de la radioterapia oncológica significó para esos pacientes la necesidad de someterse a una terapéutica con una característica de medicina-veneno que causa temor, sin embargo que era necesaria, si la meta fuese la cura o la sobre vivencia al cáncer.

DESCRIPTORES: neoplasias; radioterapia; antropología cultural; cultura; enfermería

\section{A EXPERIÊNCIA DA RADIOTERAPIA ONCOLÓGICA PARA OS PACIENTES: UM REMÉDIO-VENENO}

O estudo objetivou compreender a experiência da radioterapia oncológica para os pacientes. A abordagem da antropologia interpretativa e o método etnográfico nortearam a investigação. Foram informantes dez pacientes de ambos os sexos, na faixa etária de 34 a 80 anos, acompanhados durante o tratamento radioterápico. Os dados foram coletados por entrevistas semi-estruturadas, observação participante e levantamento em prontuários. A análise dos discursos dos informantes possibilitou a identificação das unidades de significado: o encontro com a radioterapia, o corpo como veículo de ação da radioterapia e as práticas alternativas de cuidado aliviando os efeitos do tratamento. Compreende-se, aqui, que a experiência da radioterapia oncológica significou para esses pacientes a necessidade de se submeterem a uma terapêutica com característica de remédio-veneno, que causa temor, mas que era necessária se a meta fosse a cura ou mesmo a sobrevivência ao câncer.

DESCRITORES: neoplasias; radioterapia; etnografia; cultura; enfermagem

\footnotetext{
${ }^{1}$ Paper extracted from Doctoral Dissertation; ${ }^{2}$ Assistant Professor, Faculdade de Enfermagem e Obstetrícia da Universidade Federal de Pelotas, Doctoral student, University of Sao Paulo at Ribeirao Preto College of Nursing, WHO Collaborating Centre for Nursing Research Development, Brazil, e-mail: romaniz@terra.com.br; ${ }^{3}$ Associate Professor, University of Sao Paulo at Ribeirao Preto College of Nursing, WHO Collaborating Centre for Nursing Research Development, Brazil, e-mail: mmfzago@eerp.usp.br. 


\section{INTRODUCTION}

The estimates of the National Cancer Institute - Instituto Nacional do Câncer (INCA) for Brazil, in 2008, are that 466,730 cancer cases will be registered. 231,860 new cases for males and 234,870 for females are expected ${ }^{(1)}$.

Cancer treatment aims at curing, prolonging life and improving the quality of life of the oncologic patient. For that, medical treatment protocols involving surgery, radiotherapy, chemotherapy, hormone therapy or a combination are proposed ${ }^{(2)}$. Radiotherapy is basically performed in one of two forms: external, or teletherapy, using radioactive sources of nuclear origin (Cobalt-60), or linear accelerators producing radiation through acceleration of electrons; and internal, or brachytherapy, a shortdistance therapy where an encapsulated source or a group of these sources are used to release â or ã radiation, a few centimeters away from the tumor ${ }^{(3-4)}$.

Regarding the goal, radiotherapy can be curative or palliative. Curative radiotherapy aims to cure tumors and is usually a long-term treatment (more than four weeks). Palliative radiotherapy treatment is indicated for advanced stages of the disease. It can be a short- or long-term therapy, and aims at lessening the symptoms provoked by the tumor, such as bleeding, pain relief, obstructions and neurologic compression $^{(3-4)}$.

The toxic effects of radiotherapy occur mainly in the irradiated region, and its effect is maximized when it is administered concomitantly with chemotherapy. The most common physical side effects are fatigue, radiodermitis and inappetence. These are not dependent on the application site, and usually appear after the second week of treatment ${ }^{(3-4)}$. Therefore, besides having to adjust to their new identity of cancer patients, they need to deal with the side effects of radiotherapy, which can make them feel impotent in the face of their new condition.

Considering that having cancer and submitting to radiotherapy are facts that permeate the sociocultural construction of those who experience it, we sought to answer the following question: How do patients build the meanings of the oncologic radiotherapy experience? To answer it, we defined the study objectives as the comprehension of the meanings of the oncologic radiotherapy experience for the patient and how to integrate them in sociallybuilt meanings, using interpretative ethnographic analysis.

\section{THEORETICAL-METHODOLOGICAL} APPROACH

Interpretative anthropology was the first theoretical-methodological approach used in this study, since it aims at understanding the experience in the perspective of those who actually undergo $\mathrm{it}^{(5)}$. Therefore, we decided to use a qualitative methodological approach, since it leads to the discovery of the meanings of the oncologic radiotherapy experience for the patients.

The search for anthropological methodological tools that could approximate the social group of the study, aiding in the comprehension of the meaning of these experiences, resulted in the choice of the ethnographic method, as a way of looking at this experience closer and from the inside ${ }^{(5)}$.

Ethnography is an interpretative science, since man, as a creator of culture, builds and rebuilds the meanings of the phenomena that can be interpreted. Ethnography is proposed as a dense description, where the task of the researcher is to describe social discourse, registering it and transforming it in scientific knowledge. Participative observation and in-depth interview are proposed as ethnographic data collection methods ${ }^{(6)}$.

The study was developed with ten oncologic patients who, during the data collection period, were undergoing radiotherapy at Centro Regional de Oncologia e Radioterapia (CRO), Universidade Federal de Pelotas. Data collection happened from March to August, 2007, when the patients were followed during treatment and for 30 additional days after its end. Three procedures were used for collection: participative observation, in-depth semi-structured interviews and research in medical records. The interviews were recorded with the respondents' permission and transcribed to a computer file immediately afterwards.

Four interviews were held, at the respondents' homes, lasting 60 minutes on the average. The guiding questions were: Talk about your disease - cancer. What do you think about radiotherapy? Why are you doing it? How is your life during treatment? How do you deal with your body and health?

Regarding the social characteristics of the interviewees, they were between 34 and 80 years old; six were female and four were male. One was single, six were married, one was a widow and two 
had been living with their partners for a long time. The monthly income varied from one to three times the minimum wage. The time of cancer diagnosis varied from two months to two years, and it should be noted that two of the respondents were in treatment for metastasis and died during data collection. Treatment length varied from 10 to 35 radiotherapy sessions.

With the participative observations, attempts were made to understand the spaces, persons, relations and different situations existing in the environment of Centro Regional de Oncologia e Radioterapia at Universidade Federal de Pelotas (UFPel) and patients' homes, favoring the acquisition of data that gave clues to complement the reflections about the results when contrasted with the interviews.

Data analysis occurred in four stages. First data organization, after the transcription of the interviews, observations and field notes. A horizontal map was drawn with the researchers' discoveries. The second stage - data coding, based on the research theme, objectives and theoretical assumptions. The third stage - identification of the units of sense, was considered intermediate, with the grouping of common and uncommon codes, and was also considered the first stage of interpretation with the building of the units of meaning. The fourth and last stage consisted in the definition of the meaning cores where, after deep reflection about the empirical material, in a circular motion going from empirical to theoretical, the interpretation of the group's internal logic about the oncologic radiotherapy experience was sought, in the researchers' comprehension ${ }^{(7)}$.

The project was submitted to and approved by the Review Board of Faculdade de Medicina, UFPel. The respondents signed the term of consent and were identified with pseudonyms of their own choice, in order to preserve their identities.

\section{RESULTS AND DISCUSSION}

After the units of meaning about the oncologic radiotherapy experience, the data were classified into: the encounter with radiotherapy, the body as the vehicle of radiotherapy action and common healthcare practices that relieve the effects of the treatment. With these categories, we described the meanings the interviewees gave to the oncologic radiotherapy experience.
It is worth noting that the categories were integrated based on the anthropological concept of culture $^{(5)}$ and the socioanthropologic characteristics of the interviewees.

The encounter with radiotherapy

The history of these people, until they were told of result of the biopsy for the diagnosis, was welldescribed by Marcio: The doctor told me: From now on, you're a cancer patient! (Marcio, 52 years old).

With the confirmation of the diagnosis, the patients see their life and identity change, demanding that they deal with the difference - having cancer. With the construction of webs of meaning about the disease, the respondents see themselves tied down to a path that will lead them to radiotherapy, which they fear. However, they consider it necessary, if they aim at freeing themselves from the disease.

From the moment radiotherapy was indicated, the respondents started to think about this therapy, which was unknown to them. This made them build symbols that made sense for them.

I imagine that it is like a gun, you know... looking for bad cells and killing them and a bunch of others (Nina, 53 years old). It's for killing this bug, isn't it? It's meant to dry it up, to kill it off (Anita, 70). I think it kills and burns the root (of the disease) (Maria, 51).

The knowledge of the subjects about radiotherapy gave it the sense of being a weapon to fight the enemy, cancer, showing the belief that the disease requires some sort of fighting. The construction of the treatment as a weapon reflects a universal piece of knowledge in western culture. The western meanings given to cancer see it as a cruel, untreatable and mysterious disease, which requires fighting for being something that attacks and invades the body. As such, its treatment is thought of as a counterattack, a war, which sometimes causes it to be seen as worse than the disease itself. Therefore, it is common to hear that radiotherapy is a type of bombardment with toxic rays; chemotherapy kills cancer cells. The secondary effects and their damage on the body are justifiable if cure is the goal ${ }^{(8)}$.

The way Maria considered radiotherapy, as being something "serious, dangerous, violent and that hits hard" drew our attention. She concluded by saying: It's a poison-drug! This construction is also based on its similarity with the nuclear bomb. The fear of the treatment is built upon the notion of radioactivity 
in society, influencing people's culture about this therapy and making them fearful of its results.

The perception of radiotherapy as a drug and poison normalized the actions of this group of respondents, and they projected situations that can possibly be experienced, creating strategies for action when they felt threatened. This situation had a concrete influence in their lives and encouraged them to elaborate ways to strengthen themselves, as they submitted themselves to this therapy. As mentioned by Helena, it's a daily commitment, but it can be my salvation!

The description of the marking process for radiotherapy reveals a submission of the patient's body to the practices and decisions of the professionals who, at times, remembered to talk and see him or her as a subject. Meanwhile, the patient, seemingly cooperative, described the experience as a suffering imposed by the disease later. Biomedicine still sees the body as a machine, dissociating body (physical) and mind (psychic), although some interactions are perceived between them ${ }^{(9)}$.

The comprehension of the programming and marking processes needed for the radiotherapy sessions does not only involve the description of actions, but also the interpretation of the subjective processes they cover. The occasion of the radiotherapy programming caused many feelings to surface.

I didn't know what to do, I had no idea of what I'd do! It was really tiresome, I felt really tired! I lay down for over an hour, it was very cold but I didn't even feel it. My hands were hanging, the position was cumbersome, you know... My hands were numb, my neck was stiff... that was it, physically. It was bad because it took too long. (Nina, 53)

The effective encounter with radiotherapy becomes official with the programming and marking of the area to be irradiated. This period was configured as a situation that caused intense emotions, such as feeling like one's identity had been deconstructed, the "loss of self", or because of being a moment when patients were counting on the medical discourse that radiotherapy could provide control or cure of the disease ${ }^{(10)}$.

The body as the vehicle for radiotherapy

The body is not only biological. It is elaborated by culture and is a social product, since it is constituted in the relations with other bodies in society. It is the vehicle of the being in the world, who expresses the feelings and perceptions in situations of disease, pain and suffering, revealing that we have a body and we are a body ${ }^{(10)}$.

The marking of the body caused several responses among the patients, due to its weirdness, and also because they felt different. I didn't know they were going to paint me. They didn't tell me at all. I came to know about it later, when I went there for programming (Douglas, 39). Apparently, we're not different from other people, but when we look in the mirror and see all that paint... then we realize: Wow, I'm different from the others! (Janete, 44).

According to the interviewees' reports, the radiotherapy marking paint alters the body image. They feel embarrassed of showing their body, even in their family. Therefore, marking was configured as a symbolically different identity in relation to that where the respondents recognized themselves as persons. The body is involved in the establishment of the frontiers that define who we are, serving as a base for identity. As such, when the body is modified, the person feels different in the face of others and himself or herself ${ }^{(11-12)}$.

On the other hand, the perception of the person about his or her body with the paint leads to a daily recollection of the diagnosis, of the difference in relation to the other. Beause of that, the last day of treatment represented a liberation, since the disease could remain hidden in the subconscious mind: I came home and I was aching for a shower to get all that red paint off. It seems like... every time I changed clothes I'd look at that, and it all came into my mind: I've got cancer! I didn't even want to remember this word, you know. Then, without all that red paint on my body, I felt relieved, because it seemed like that wouldn't come to my mind all the time (Helena, 55).

Thus, we learned that the experience of skin demarcation for radiotherapy in this group of patients brought feelings such as anguish and worries, due to the alteration of the body image, and embarrassment, because they felt different from the people in their social context. The radiotherapy map had a meaning of social difference, being another stigma and increasing suffering. Certain diseases and treatments, such as cancer and radiotherapy, increase the determination for a stigma, due to the body damages caused by physical deformations, visible marks, stained skin and revolting appearance, which affect social relations and life $^{(13-14)}$.

The body also suffers the manifestation of the radiotherapy side effects, i.e. the individual and social bodies also suffer the action of treatment. This 
happens because, besides having to live with the physical effects (diarrhea, radiodermitis, nausea and vomiting), these affect the emotional dimension of the individuals who need it ${ }^{(15)}$.

The patients' physical responses to radiotherapy are in agreement with literature ${ }^{(3-4)}$. For them, the responses were: skin reaction on the application site: [...] it's all burnt, because I've got dry skin, and now, girl, it's all charred. It's pitch black. I'm turning black from here (points to her stomach) downwards (Anita, 70); The fear of radiodermitis, among the patients, was influenced by common sense and related to body functioning, distinguishing one body from the other: [...] when I started radiotherapy, people told me: Man, you'll see, that burns and leaves a wound. I told them: I'm gonna do it, not all bodies are alike! (Luiz Carlos, 80); diarrhea for over 10 days and fatigue were effects that incapacitated the interviewees for the performance of everyday activities: [...] I suffered! Whew, there were days when I'd take as many as 6 pills (Imosec) a day, not to mention the tea. And those terrible cramps, and the diarrhea. (Helena, 55). Oral disorders were appointed only by Maria, since her treatment involved head and neck: [...] I feel my mouth get dry, food has no taste, I feel something weird in my stomach, something that shouldn't feel like that (Maria, 51). The wellknown "ray disease" was also present, which manifests itself a few hours after application, with varying degrees of sickness, nausea, anorexia and vomiting: [...] I couldn't even smell them having lunch, the smell of food, I spent the day in bed and ate nothing. I had strong nauseas (Helena, 55).

Therefore, since the body is the vehicle for our perceptions, it expresses our feelings and is the place where the disease, pain and suffering give meaning to the therapy experience ${ }^{(3)}$. When it suffers a visible and significant physical change, the body can transform into another, sick, crippled, lacking integrity and autonomy, leading to internal conflicts and imbalances, such as low self-esteem because of alterations in the body image $\mathrm{i}^{(11,14)}$.

The pain is horrifying, isn't it? I can still feel the effects, it's horrible, horrible! Each patient must feel that theirs is terrible. It's really, really bad. It hurts a lot, it bothers a lot. We even forget about the disease itself, that we've got cancer! Because we have to fight what is happening right there, you know? (Nina, 53).

The narration describes the suffering the patient had to endure because of the treatment effects. She perceived that she was losing control over her physical body, becoming inept for activities that were her responsibility. As implied by the patient, the household chores were important for Nina, a member of the low-income class and who performed her social roles of homemaker and seamstress.

The person with a chronic disease develops a disintegrated self-image, with the association of several images due to the negative experience. Suffering does not happen only with physical discomfort, but the main sources are the restrictions in life, social isolation due to indisposition, burns, and the feeling of being a burden because of the loss of autonomy ${ }^{(14)}$.

Thus, at several moments during the radiotherapy, we observed that the physical responses appointed by the respondents integrate with the emotional responses and suffering, since the changes in the conceptions of the cancer patient's self involve identity and the body. Both are part of the unit of the person, and can be in harmony or in conflict, since the self rebuilds itself permanently ${ }^{(10,15)}$.

The common healthcare practices that relieve the effects of the treatment

With the objective of relieving the effects of radiotherapy, this group of patients used common healthcare practices learned in the family's cultural context, with friends, through the media and also through the official healthcare system.

Among the usual practices, the use of phythotherapy products was the most common: [...] I drink cocão (Sebastiania serrata) tea. Many people say it cures. I've been taking it since I began treatment. (Nilson, 65); Chamomile (recommended by professionals) and Aloe Vera: [...] I started using teas and washing with chamomile tea, and I used Aloe Vera too... (Nina, 53). The last two are indicated to relieve radiodermitis, both orally and topically.

Other situations when herbs needed to be used to control the effects of the treatment:

[...] I had to go for tea, the diarrhea pills alone don't work. Then, a lady said that the leaf of the pitanga tree (Eugenia uniflora) with the peel of pomegranates would help. I've been drinking it since this morning. (Helena, 55). [...] Marcela (Achyrocline satureioides) is good for inflammations, and I'd wash my mouth with that. Marcela, chunk salt and chamomile too... (Maria, 51).

We noticed that the use of herbs for treatment underwent evaluations that consisted in the verification 
of their curative or palliative properties, and whether they were effective or not. This process was experienced by the patients and their family network.

This group of respondents showed some differences among its members. While some used all resources available for the disease and therapy (teas, astral surgery, reiki, blood self-transfusion), others used only teas to relieve the symptoms of radiotherapy, i.e. to treat the effects of the poison-drug.

Another way of dealing with cancer and radiotherapy appointed by the respondents was the search for religious healing rituals. The meaning the respondents gave to the religious rituals seemed to relate to the belief in the supernatural, either to cure or to help them cope with the suffering caused by the disease and the treatment: There was a campaign this week, they do it for three days in a row, it's a cult for cure and liberation. (Helena, 55)

Therefore, religion, by using symbols, provides explanations for the perceived ambiguities, the paradoxes of human experience and the unexplainable events, due to the chaos triggered by the disease, integrating them to a sacred logic. The quest for God's help points to a symbolism of an almighty supreme power, and that will help them at this moment of anguish, suffering and despair. Religion, as a support in difficult times, is a sociocultural conception learned in the family environment and in the social group the person is inserted in ${ }^{(14)}$. The type of religion is not important. What matters is the spiritual support it provides for the hope of a better life, as said by Helena: [...] I placed it in the hands of God, my greatest physician!

\section{FINAL CONSIDERATIONS}

The cultural interpretation adopted in the study for this group of interviewees, about the radiotherapy experience for cancer, was a methodological tool that enabled the construction of knowledge about healthcare for adults with chronicdegenerative diseases like cancer. Therefore, the ethnographic fieldwork was configured as the fundamental element to describe the human experience in detail, when dealing with the healthdisease process.

The study also made it possible to apprehend that the radiotherapy symbology is built little by little, as the respondents undergo the treatment sessions. This process is experienced everyday, for approximately five weeks, and makes the patient face the disease and the limitations imposed by the treatment. This construction contributes to the full comprehension of the aspects that compose the process of falling ill, and those that are incorporated in the experience of treatment for the tumor, that give meaning to the recovery of the social and individual body.

The radiotherapy experience was configured as a cyclic period, permeated by situations that marked these people: Entering the world of radiotherapy represented the discovery of another identity, which has to face its disease; even when the radiotherapy map no longer existed on the physical body, it was still present in the psychosocial body, due to intense and significant emotions; the daily commitment with the sessions and the responses in the face of the demarcation or even the adverse effects that flagellated their physical bodies; and, lastly, but not least important, the search for the cure and relieve of the radiotherapy effects in the popular healthcare system.

The comprehension of the group of interviewees about the course of the radiotherapy, from the perspective of drug, was configured as the moments when they sought the cure for their disease, submitting themselves to radiotherapy, because they had the idea that it was necessary and important for their survival. On the other hand, radiotherapy was configured as a poison when its toxic effects caused suffering in the psychic and physical body, and made them incapable of performing their daily activities. Thus, we learned that, in the perspective of the subjects, the radiotherapy experience is a sequence to the suffering undergone since cancer was diagnosed; in the face of the conflict between the cure and being submitted to the treatment.

Therefore, the meaning of the oncologic radiotherapy experience for this social group was the need to submit to a therapy with a poison-drug characteristic, which causes fear, but which is necessary if the goal is cure or even cancer survival.

Finally, we understand that the meanings appointed herein about the oncologic radiotherapy experience can serve as the base for nursing actions in care delivery to this clientele, by observing the sociocultural context it happens in. 


\section{REFERENCES}

1. Ministério da Saúde (BR). Secretaria de Atenção a Saúde. Instituto Nacional do Câncer. Coordenação de Prevenção e Vigilância do Câncer. Estimativa 2008: Incidência do câncer no Brasil. Rio de Janeiro (RJ): INCA; 2007.

2. World Healt Organization (WHO). Are the number of cancer cases increasing or decreasing in the world? [updated 2005 May 13] Available from: http://www.who.int/en/. [cited 2006 Jun 28]

3. Dow KH, Bucholtz JD, Iwamoto RR, Fieler VK, Hilderley LJ. Nursing Care in Radiation Oncology. 2nd ed. WB Saunders Co; 1997.

4. Ministério da Saúde (BR). Instituto Nacional do Câncer. Ações de enfermagem para o controle do câncer: uma proposta de integração ensino-serviço. 2 ed. Rio de Janeiro (RJ): INCA; 2002 .

5. Geertz C. A interpretação das culturas. Rio de Janeiro (RJ): Guanabara Koogan SA; 1989.

6. Uchôa E, Vidal JM. Antropologia médica: elementos conceituais e metodológicos para uma abordagem da saúde e da doença. Cad Saúde Pública 1994 outubro/dezembro; $10(4): 497-504$
7. Hammersley M, Atkinson P. Ethnografhy: principles in practice. New York (USA): Routledge; 2007.

8. Sontag S. A doença como metáfora. Rio de Janeiro (RJ): Edições Graal; 1984.

9. Garro L. Narrative representations of chronic illness experience: cultural models of illness, mind and body in stories concerning Temporomandibular Joint (TJM). Socl Science Med; 1994; 38(6):775-88.

10. Adam P, Herzlich C. Sociologia da doença e da medicina. Bauru (SP): EDUSC; 2001.

11. Maruyama SAT, Zago MMF. O processo de adoecer do portador de colostomia por câncer. Rev Latino-am Enfermagem 2005 março/abril; 13(2): 216-22.

12. Silva TT, Hall S, Woodwart K. Identidade e diferença: a perspectiva dos estudos culturais. 6a ed. Petrópolis (RJ): Ed Vozes; 2006.

13. Canesqui AM, organizadora. Olhares socioantropológicos sobre os adoecidos crônicos. São Paulo (SP): Hucitec; 2007. 14. Helman CG. Cultura, saúde e doença. 4 ed. Porto Alegre (RS): Artmed; 2003.

15. Anjos ACY, Zago MMF. A experiência da terapêutica quimioterápica oncológica na visão do paciente. Rev Latinoam Enfermagem 2006 janeiro/fevereiro; 14(1): 33-40. 